\title{
Ethnobotanical Study with Native Species in a Rural Village in Piauí State, Northeast Brazil
}

\author{
Francisco das Chagas Dourado de Sousa ${ }^{1}$, Melise Pessôa Araújo ${ }^{2}$, Jesus Rodrigues Lemos ${ }^{3,}$ * \\ ${ }^{1}$ Biologist, autonomous Professional, Buriti dos Lopes, PI, Brazil \\ ${ }^{2}$ Federal University of Piauí, Campus Helvídio Nunes de Barros, Rua Cícero Eduardo, Picos, PI, Brazil \\ ${ }^{3}$ Federal University of Piauí, Campus Ministro Reis Velloso, Av. São Sebastião, Parnaíba, PI, Brazil \\ Email address: \\ chaguinhadourado@hotmail.com (F. das C. D. de Sousa), melisepessoa@yahoo.com.br (M. P. Araújo), jelemos@ib.usp.br (J. R. Lemos)
}

\section{To cite this article:}

Francisco das Chagas Dourado de Sousa, Melise Pessôa Araújo, Jesus Rodrigues Lemos. Ethnobotanical Study with Native Species in a Rural Village in Piauí State, Northeast Brazil. Journal of Plant Sciences. Vol. 3, No. 2, 2015, pp. 45-53. doi: 10.11648/j.jps.20150302.11

\begin{abstract}
Over the years, Ethnobotany has evolved and contributed with information about the use of plants by traditional communities. Further more, it acts as a source of important information for the conservation of biomes and use of plant species in medical, pharmaceutical and biotechnological areas. A survey of species of native vegetation used for different purposes in Serragem village, in the municipality of Buriti dos Lopes, northern Piauí, Brazil was conducted through semi-structured interviews, using the "snowball" sampling method and the "tour guided" technique with 20 inhabitants who had a greater knowledge of the local flora, and has identified 60 species into 52 genera and 27 botanical families. Fabaceae was the most representative in terms of number of species. Copernicia prunifera, Parkia platycephala and Myracrodruon urundeuva were the species with the highest Use Value (UV). Medicinal use category (33\%) was the most representative, followed by food use $(22 \%)$ and timber use $(19 \%)$. The use of native vegetation for several purposes is still a practice that has been quite common among villagers, and has a fundamental importance for it serves as alternative to perform many daily activities.
\end{abstract}

Keywords: Traditional Knowledge, Use Category, Piauí State-Brazil

\section{Introduction}

Since the dawn of civilization, men have searched alternatives through natural resources to improve their own living conditions, thus increasing their chances of survival. The various ways of use of plant resources by communities are diverse and important in various cultures, such as for food and medicinal purposes, and for housing construction [1].

Over the years, Ethnobotany has evolved and currently contributes with information concerning the use of plants by traditional communities. It also acts as source of important information for the conservation of biomes and use of plant species in pharmaceutical, medical and biotechnological areas $[2,3,4]$.

Traditional communities are the basis of knowledge on the use of medicinal plants (for several purposes) and have been modified over time by the growing urbanization and the lack of interest among youngsters in these communities, which turns such knowledge increasingly fragmented, interrupting the process of knowledge transmission from generation to generation [5].

Studies regarding the use of plants for medicinal purposes developed by Ref. [6] demonstrated growing academic interest in popular medicine, especially after it was known that the empirical basis can often have scientific evidence and that the analysis of exploitation of the environment by traditional peoples provides information for management strategies and appropriate use of certain environments [7].

The consumption of medicinal plants is based on family tradition and became widespread in folk medicine. Currently, many factors have contributed to the increased use of this resource, including the high cost of manufactured drugs, the difficult access of the population to health care, and the tendency to use natural origin products nowadays [8]. In Piauí state, Brazilian Northeast, many ethnobotanical studies were carried out, some of them highlighted medicinal aspects $[9,7,10,11,12)$, timber aspects [13], toxic plants [14] and even addressed different categories of use $[15,16,17,18,19$, $20,21,22,23]$, but only studies of Ref. [10], in the municipality of Cajueiro da Praia, addressed medical aspects, and the ones of Ref. [23], held in Morro Mariana and Barra Grande, addressed various categories of use made in the far 
north of this State.

Thus, this article raises some species of native vegetation that are known and used for different purposes by villagers in Serragem, in the municipality of Buriti dos Lopes, northern Piauí, Brazil, in order to know the plant resources in the area and how they are managed.

\section{Material and Methods}

\subsection{Study Area}

The municipality of Buriti dos Lopes $\left(03^{\circ} 10^{\prime} 30^{\prime \prime} \mathrm{S}\right.$ and $41^{\circ} 52^{\prime} 01^{\prime \prime} \mathrm{W}, 50$ m.a.s.1.) is located in the microregion of Piauí coast, $281 \mathrm{~km}$ away from Teresina [24], bordering north with the city of Parnaíba; south with the municipality of Caxingó; east with Bom Princípio, and; west with the state of Maranhão. It covers an area of $524.22 \mathrm{~km}^{2}$, with 18.598 inhabitants and a population density of 35.49 hab. $/ \mathrm{km}^{2}$, where $49,82 \%$ of people live in rural areas [24].

The vegetation is characterized by the shrubby-arboreal transition Cerrado/Caatinga. The tropical climate is alternately wet and dry, with a long dry period of six months and temperatures ranging between $25^{\circ} \mathrm{C}$ and $34^{\circ} \mathrm{C}$ [25].

The research was carried out in the village of Serragem, in the rural area of Buriti dos Lopes, $7 \mathrm{~km}$ away from the municipal seat through the access at the $\mathrm{km} 43$ of highway PI 343 [26]. The village has 20 residents, who rely on familybased agriculture of corn, beans, cassava, and on raising small animals for their own consumption as their main means of subsistence.

\subsection{Data Sampling and Analysis}

\subsubsection{Ethnobotanical Data}

Twenty residents of the village were interviewed from September 2013 to April 2014. The sample size was determined by the "snowball" technique [27], in which informants in the village who had a broader knowledge of the flora were nominated. In order to so, we applied semistructured forms about knowledge and use of native plants, and we also registered the respondents' socioeconomic data to characterize the environment in which this knowledge is embedded.

The age range of the informants during the interviews was defined according to Ref [28]: young adults (between 18 and 24), adults (between 25 and 59) and elderly (older than 60). The "guided tours" [29] were done with the help of residents ('bushman guides') who had a greater knowledge of the area and the plants used around their homes, in backyards and on the far woods to their homes. The use of this methodology is of fundamental importance since informants may contribute the already mentioned information and with new information during the collection of botanical material, such as the vernacular names of the plants and their attributes, which can be related to use categories such as medical, food or fodder [30].

For each of the species mentioned by the residents its Use Value (UV) was calculated as Refs. [31,32], modified by Ref.
[33], from the formula $U V=\Sigma U / n$, where $U=$ number of ethnospecies quotations by informant, and $n=$ number of respondents who cited the ethnospecies.

Interviews were conducted in the homes of the study site, respecting the availability of the interviewee in order not to interfere in their daily routine. The species were grouped based on categories of use proposed by Ref. [34], such as medical, food, timber, energy, fodder and toxic, and diseases of the medical category classified according to the World Health Organization [35].

\subsubsection{Botanical Data}

The procedures used in plant taxonomy studies [36] were followed for the collection of botanical material.

The identification was performed by comparison to the material already incorporated into herbarium, specialized literature and/or by sending it to taxonomists. The angiosperm species were classified and the floristic list sorted alphabetically by family as proposed by the Angiosperm Phylogeny Group III [37]. The dried specimens were mounted and incorporated in the Herbarium 'HDelta' at the Federal University of Piauí/Campus Ministro Reis Velloso. The botanical synonyms were updated using the database available in the website "List of Plant species of Brazil" [38].

\section{Results and Discussion}

\subsection{Profile of Residents}

In the analyzed group, $75 \%$ are men and $25 \%$ women. $65 \%$ out of the total come from the municipality of Buriti dos Lopes, Piauí; $10 \%$ from the city of Granja, Ceará; $10 \%$ from the city of Parnaíba, Piauí; $10 \%$ are native to the site and $15 \%$ are from the city of Araioses, Maranhão. The predominance of men in ethnobotanical research was also observed by other authors [19, 7, 39, 40]. According to Ref. [18], men have greater knowledge of native species found near and farther away from their residences, and they were used in energy production, forage and as timber, while women have extensive knowledge of exotic and native plants very close to their homes, which are used for medicinal purposes. This context is similar to that observed in other areas of the country, as in the studies performed by Ref. [41] in the Cairuçu Environmental Protection Area, Rio de Janeiro, and by Ref. [42] in Cardoso Island, São Paulo.

The average time of residence in the village varied from one to 60 years, and $55 \%$ of residents live in the village within one to eight years; $30 \%$ were $12-40$ years old and $15 \%$ were $52-60$ years old. Out of the total of residents, $20 \%$ are illiterate, $75 \%$ have incomplete elementary education and $5 \%$ have completed high school. Regarding marital status, $75 \%$ are married, $15 \%$ are single and $10 \%$ are widowed.

All informants classified themselves as farmers, which is the main occupation in the village. Economic activity is based on subsistence agriculture, such as the cultivation of corn, beans and cassava. About $40 \%$ of respondents survive on a minimum wage, $25 \%$ are retired, $25 \%$ less than the minimum wage and $10 \%$ with federal government subsidy 
("Bolsa Familia"). 75\% of households have two to five residents and $25 \%$ up to 11 people.

Regarding the aspects related to basic infrastructure, residents live in their own homes with simple structure, with tile roofs and electricity in every home. The lack of school and health center makes the villagers move to the municipal seat or other nearest town to have access to education and health.

\subsection{Floristic Survey}

Sixty taxa were identified distributed in 52 genera and 27 families (Table 1). The families with the highest number of species were Fabaceae (16 species), Combretaceae (4 species), Anacardiaceae, Apocynaceae, Myrtaceae and Rubiaceae (3 species each). Similar results were reported by Ref. [43], studying the quilombola community Mimbó, in
Amarante, Piauí, which registered 57 ethnospecies, highlighting the Fabaceae family with 17 useful species, followed by Combretaceae, Anacardiaceae and Apocynaceae. Other ethnobotanical research carried out in Piauí found the Fabaceae family as the most representative in number of species, with prominence to the study made by Ref [18] in rural communities in the semiarid region of Piauí; Ref [16] in Quilombo Olho D'água dos Pires, in Esperantina; Ref [15,17] studying the economic potential of the Carrasco vegetation flora in the municipality of Cocal; Ref [21] checking the ethnobotanical knowledge of traditional communities in Serra de Campo Maior; Ref. [20] studying the use and diversity of plant resources used by the community Quilombola dos Macacos, in São Miguel do Tapuio and Ref. [19] studying Cerrado vegetation areas in the municipality of Monsenhor Gil.

Table 1. Species used by villagers of Serragem, in Buriti dos Lopes, Piaui state. Conventions: CN = Common Name; CAT. U. = Category of Use: a) food, b) timber, c) medical, d) energy production, e) fodder, f) craft, g) toxic; i.l.) identified on site; $C N=$ Collector Number; H=Habit; UV = Use Value.

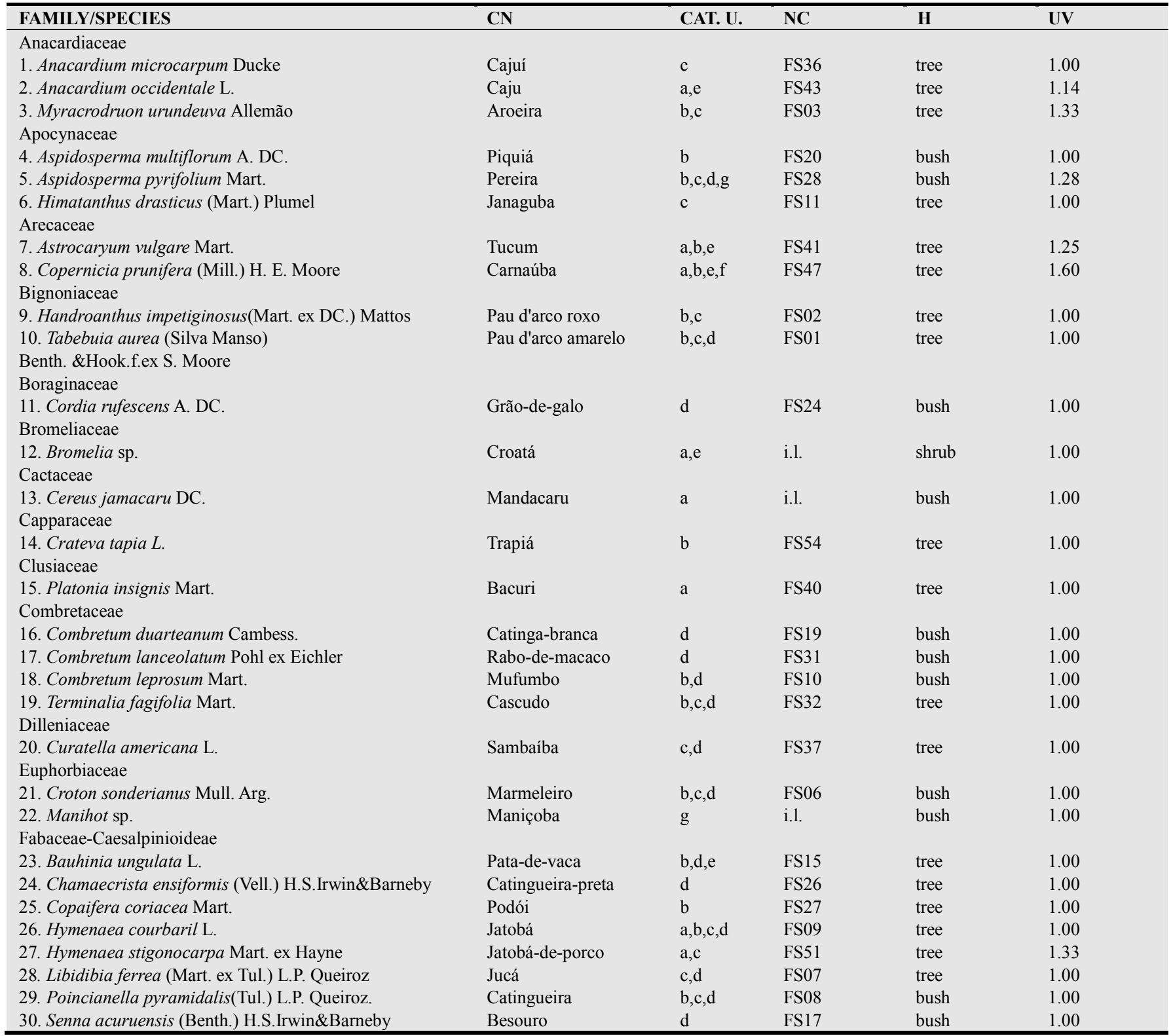




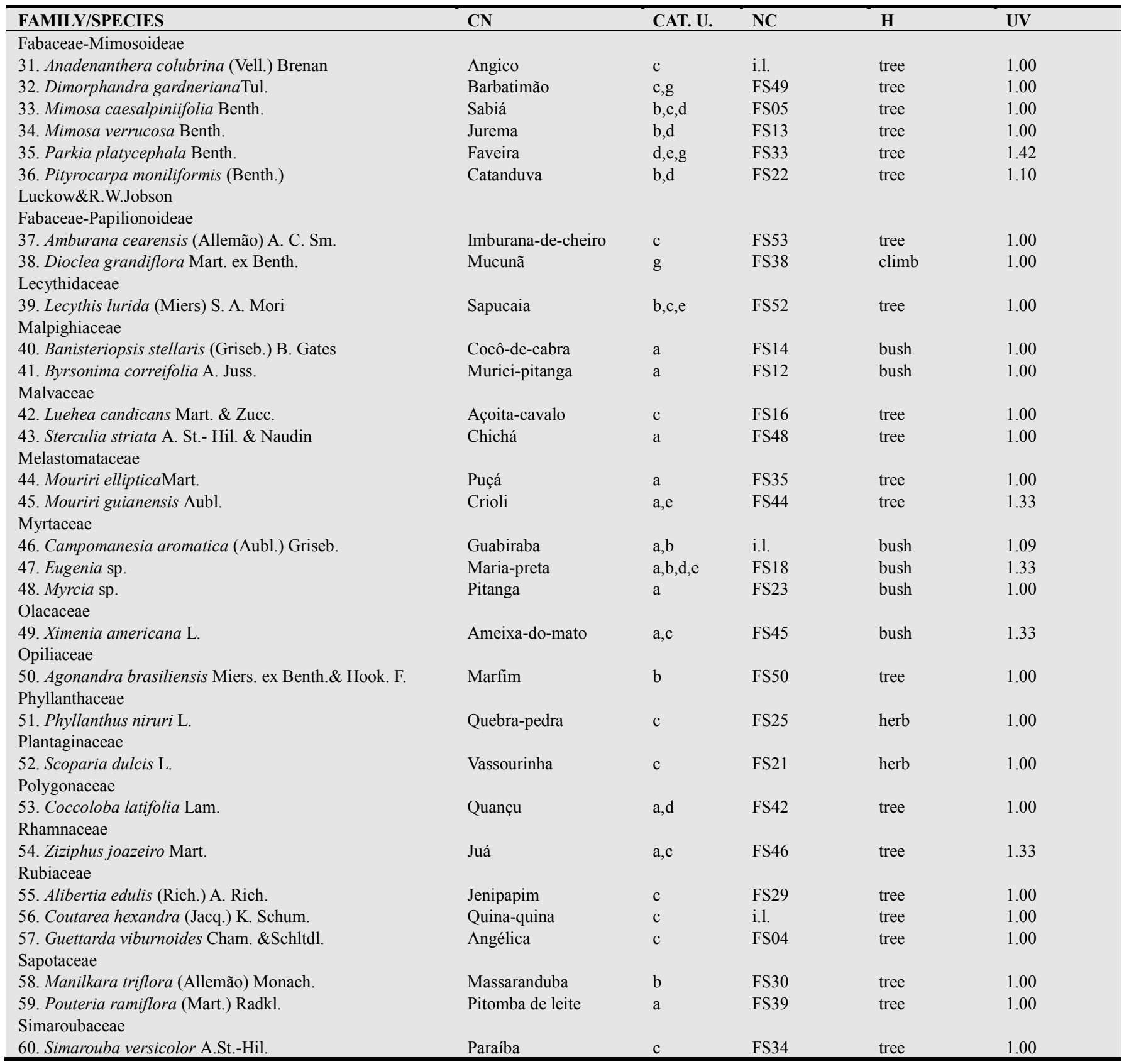

Regarding the Use Value (UV) assigned to each species, $73.33 \%$ of ethnospecies have value equal to 1.00 while $26.67 \%$ have values in the range of 1.09 to 1.60 .

The species with higher Use Value (UV) were Copernicia prunifera $(\mathrm{UV}=1.60)$, Parkia platycephala $(\mathrm{UV}=1.42)$ and Myracrodruon urundeuva, followed by Hymenaea stigonocarpa, Mouriri guianensis, Eugenia sp., Ximenia americana and Ziziphus joazeiro (UV=1.33 each). Copernicia prunifera also obtained a high UV in the study by Ref. [20], in Quilombo dos Macacos, a community in São Miguel do Tapuio, Piauí, and by Ref. [23], in the communities of Morro Mariana and Barra Grande, Piauí. Among the species most frequently mentioned by villagers, Myracrodruon urundeuva (aroeira) stands out with 5.81\%, also observed by other authors [20,44], Ximenia americana (ameixa do mato) with 5.23\%, Hymenaea courbaril (jatobá) with 4.95\%, Copernicia prunifera (carnaúba) and Astrocaryum vulgare (tucum) both with $4.36 \%$, Terminalia fagifolia (cascudo) with $4.07 \%$, Parkia platycephala (faveira) and Poincianella pyramidalis (catingueira) with $3,20 \%$, Himatanthus drasticus (janaguba) with $2.62 \%$ and Amburana cearensis (imburana-de-cheiro) with 2.32\%. All other species together accounted for $59.88 \%$ of the citations of the residents.

Ximenia americana, Astrocaryum vulgare and Copernicia prunifera were also referred to as the most frequently cited species by Ref. [21] which studied the ethnobotanical knowledge of rural communities in Serra de Campo Maior, Piauí.

In Piauí, many ethnobotanical studies [16, 21,11] mention Ximenia americana as one of the most cited species in different study areas. 


\subsection{Categories of Use}

The medicinal plants are used in the preparation of garrafada (infusion of plants in water or alcohol), tea and syrup, and as food for residents, because most fruits of native vegetation are available in the natural environment and are consumed by residents in natura or in juices. Regarding the use of vegetation with timber aspects, the plant resources available to residents are those that support the construction of roof for the houses, as well as in the construction of fences in backyards, corral pens for livestock and sties for goats and pigs. Thus, seven categories were found, and medical obtained the highest number of citations, followed by food, timber, energy, fodder, toxic and craft (Fig. 1).

Similar results for the prevalence of the medical category in ethnobotanical studies were found by several authors $[15,16,18,20,22,39,45]$, all carried out in Northeastern Brazil and encompassing the states of Piauí, Maranhão and Rio Grande do Norte.

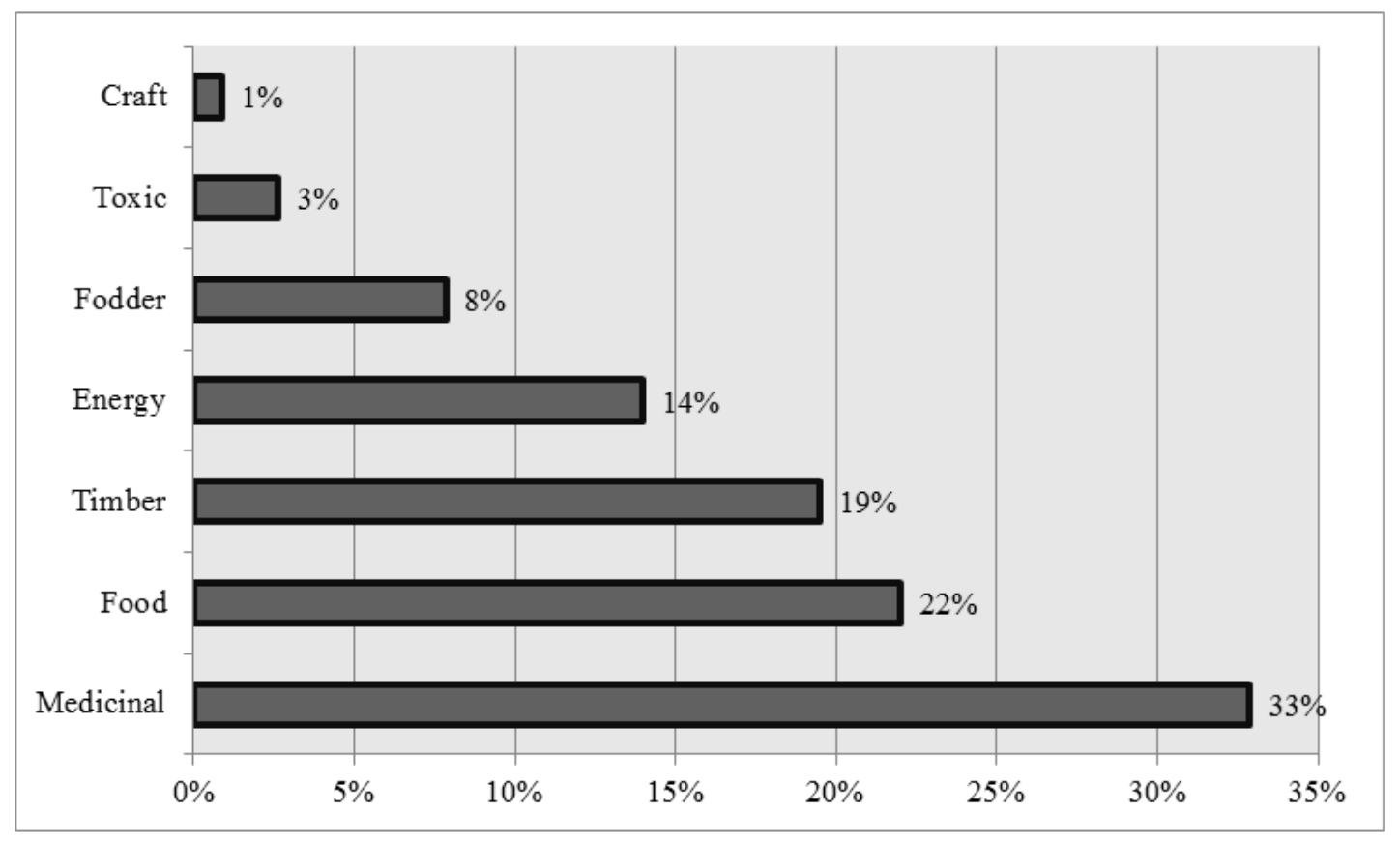

Figure 1. Categories of use found in the village of Serragem, in the municipality of Buriti dos Lopes, Piaui state. Source: Direct Research (2014).

The results obtained for the medicinal plants demonstrated that the category represents a strong element in the local culture for the treatment of signs and symptoms of disease, thereby resulting in a greater number of citations (113), which corresponds to $33 \%$ of raised species. The Fabaceae family was represented with eight species, an all were trees and shrubs. Similar results were observed in the research of Ref. [19] in the municipality of Monsenhor Gil, Piauí state, where species such as Libidibia ferrea (jucá) and Poincianella pyramidalis (catingueira) were also indicated by the villagers participants of the study for the treatment of inflammation in general.

The most common way of administering the medicinal plants is orally, in the form of 'garrafadas' $(37.96 \%)$, juice (29.62\%), tea infusion $(13.90 \%)$, syrup $(12.96 \%)$, and tea decoction (5.56\%). Regarding topical use, residents reported using the powder for several types of treatments that, according to them, consists in using specific dry parts of the plant (bark, leaves and/or fruit) and trample them with the pestle until turn them into a powder that isspread on the wound. The species Libidibia ferrea and Terminalia fagifolia were cited to heal wounds, Simarouba versicolor used in the treatment of itching in the body, and Alibertia edulis used to twists in articulations.
Another way of topical administration widely mentioned by the residents was the use of the bark of plants soaked in water for a certain period and then used as an anti-dandruff lotion. The species Ziziphus joazeiro and Aspidosperma pyrifolium were cited for this purpose.

The parts of the plants used were the stem bark, which was quite representative among residents $(77.81 \%)$, followed by latex (7.96\%), fruits (7.07\%), leaf $(4.42 \%)$ and root $(2.65 \%)$. Similar results for the use of stem bark were found in studies by Ref [46], which investigated the medicinal tree species in Marajá, in the municipality of Caxingó, Piauí; Ref [11], which studied the use of medical resources from Carrasco in the Environmentally-Protected Area in Serra da Ibiapaba, Piauí; Ref [44], in the rural community of Laginhas, in the municipality of Caicó, in Rio Grande do Norte; Ref. [47], in Caatinga area in São José de Espinharas, Paraíba, and; Ref. [48], which studied the medicinal plants cited by populations surrounding a conservation unit area of the Caatinga, in Rio Grande do Norte, coinciding with the data found in this study.

Concerning the use of the plant bark, Ref. [49], which studied the traditional botanical knowledge in Alagoinha, Pernambuco, found that the use of bark by the residents of the Caatinga communities is associated to the fact that this part is available throughout the year. 
With respect to plants with medicinal uses, several forms of administration were recorded as, e.g., Myracrodruon urundeuva used in the treatment of inflammation, influenza and wound healing; Anacardium microcarpum, Ximenia americana and Himatanthus drasticus to inflammation of the uterus; Termilalia fagifolia used for liver disease; Phyllanthus ninuri for kidney problems and Simarouba versicolor for skin conditions.

Amburana cearensis, Libidibia ferrea, Hymenaea courbaril, Myracrodruon urundeuva and Ziziphus joazeiro were also mentioned as medicines in rural communities in Oeiras, in the semiarid area of Piauí, by Ref. [7]; in the communities Morro Mariana and Barra Grande by Ref. [23]; in Alagoinha, Pernambuco, by Ref. [49], and; in a rural community in the municipality of Cuitegi, Paraíba, by Ref. [50].

Out of the total number of species, 11 were mentioned exclusively in the medicinal category, represented by Alibertia edulis, Amburana cearensis, Anadenanthera colubrina, Anacardium microcarpum, Coutarea hexandra, Guettarda viburnoides, Himatanthus drasticus, Luehea candicans, Phyllanthus niruri, Scoparia dulcis and Simarouba versicolor.

Amburana cearensis (imburana de cheiro) was one of the species that were often mentioned by the residents, coinciding with the results obtained by Ref. [44], and its bark used in conjunction with the Anadenanthera sp. (angico) in the preparation of garrafadas (infusions) for the treatment of influenza, sinusitis and inflammation. Another species that obtained a significant number of citations by the residents was Himatanthus drasticus (janaguba), whose latex is used with water to treat inflammation, influenza and kidney inflammation.

Another species that deserves was highlighted in the report of the residents is Terminalia fagifolia (cascudo), used for influenza, swelling of the stomach, liver inflammation, inflammation in general, gastritis and wound healing, used through garrafadas, a common practice by the residents, prepared with the stem bark mostly boiled with water and subsequently stored in glass bottles.

The use of native vegetation as food stands out as the second most cited category, accounting for $22 \%$. The plants are used in general, they are available in the residents' backyards and, in most cases, in the far forest of households, and they are consumed in natura or in juice. The Caatinga vegetation has native plants that even fruit in the most severe conditions, thus helping to keep the man and the native fauna living there alive [51].

Regarding the most representative families in the food category, Myrtaceae (3 species), Arecaceae, Melastomataceae, Fabaceae and Malpighiaceae (2 species), Anacardiaceae, Bromeliaceae, Cactaceae, Clusiaceae, Polygonaceae, Malvaceae, Olacaceae, Rhamnaceae and Sapotaceae (1 species each) stand out. The Myrtaceae family was also representative in number of food species in the research by Ref. [19] in the municipality of Monsenhor Gil, Piauí, and the research by Ref. [21] in the communities Pau-Arrastado, Salinas and Resolvido, in the Serra de Campo Maior, Piauí state.

Among the edible species cited by residents, we highlight, in number of citations, Ximenia americana, Mouriri elliptica, Mouriri guianensis, Byrsonima correifolia, Pouteria ramiflora, Campomanesia aromatica, Hymenaea courbaril, Sterculia striata, Platonia insignis, Anacardium occidentale, Astrocaryum vulgare, Copernicia prunifera, Coccoloba latifolia, Ziziphus joazeiro and Cereus jamacaru, and the latter had its fruit also mentioned as food by Ref. [52] in the rural communities Besouro and Barroquinha, in the municipality of Lagoa, Paraíba, and also by Ref. [45] in a rural community in the semiarid area in Rio Grande do Norte. In addition to the fruits of those species, Sterculia striata (chichá) also had its seeds mentioned as food and prepared in the same way as the nut of Anacardium occidentale (cashew), i.e., baked in a wood fire.

Ximenia americana and Pouteria ramiflora were also cited by Ref. [19] in the municipality of Monsenhor Gil, Piauí state, and Anacardium occidentale, Hymenaea courbaril and Ximenia americana were observed in the research by Ref. [15] in the municipality of Cocal, Piauí state, and Ref. [39] in the community Canárias Island, Maranhão state.

The species Byrsonima correifolia, Ziziphus joazeiro, Sterculia striata and Copernicia prunifera were also referenced by Ref. [18] in rural communities in the semiarid region of Piauí state.

As to the timber category, families of species cited were Fabaceae (7 species), Arecaceae, Bignoniaceae, Apocynaceae, Combretaceae and Myrtaceae (two species each), Anacardiaceae, Capparaceae and Opiliaceae (one species). It was observed that the locals use wood species of native vegetation, such as Mimosa caesalpiniifolia, Terminalia fagifolia and Myracrodruon urundeuva, for different modalities, such as building fences and forks for homes. Myracrodruon urundeuva is also used as a fence post due to its strength and long durability.

In construction, residents reported using Copernicia prunifera as slats and lines to the roof of houses, and also to build corrals for livestock. Aspidosperma pyrifolium and Aspidosperma multiflorum were reported in the area as used to make rafters for the roof of houses, and handle of tools such as sickles, axes and hoes, because they are sturdy and have a long life. Aspidosperma multiflorum, Combretum lanceolatum, Crateva tapia, Copaifera coriacea, Agonandra brasiliensis and Manilkara triflora received citations only for the timber category. It was observed that the species Agonandra brasiliensis, Mimosa caesalpiniifolia, Terminalia fagifolia, Copernicia prunifera and Manilkara triflora were mentioned by the locals as resistant woods, in addition to being available more often in the village's vicinity. Aspidosperma pyrifolium and Copernicia prunifera were also referenced by Ref. [20] and are used as battens, rafters and lines in the construction of houses in Quilombo dos Macacos, São Miguel do Tapuio, Piauí state. The species Aspidosperma multiflorum, Crateva tapia, Copaifera coriacea, Agonandra brasiliensis and Manilkara triflora were cited only in the timber category. 
Regarding the category energy production, it was observed that the community residents withdraw woods to be used as fuel in the form of coal and firewood from the natural vegetation near the backyard or, most of the time, far away from their homes. Fabaceae (9 species) and Combretaceae (4 species) were the most representative families in number of species cited by residents for this category, coinciding with the results of Refs. [18,19]. Apocynaceae, Bignoniaceae, Boraginaceae, Dilleniaceae, Euphorbiaceae, Myrtaceae and Polygonaceae were represented by only one species, because, according to residents, they are not good quality wood for this practice.

For the above category, 20 species were cited $333.33 \%$ of the total) and Poincianella pyramidalis, Pityrocarpa moniliformis, Croton sonderianus, Mimosa caesalpiniifolia, Combretum leprosum and Mimosa verrucosa were the most used species by residents in the village. On the other hand, when Ref. [18] studied the rural communities of the semiarid region in the southeast of Piaui state, found results different from the ones here, for species such as Cenostigma gardnerianum, Combretum mellifluum and Terminalia brasiliensis were the most mentioned species. Cordia piauhiensis, Combretum duarteanum, Combretum lanceolatum, Senna acuruensis and Chamaecrista ensiformis were cited only for the category energy production, according to residents, because they are easily accessible on their dayto-day lives.

The plants mentioned for the category fodder support the farming of small animals (goats, pigs, horses and cattle). Arecaceae and Fabaceae families were represented by two species, while Bromeliaceae, Lecytidaceae, Melastomataceae, Anacardiaceae and Myrtaceae, by one species. Anacardium occidentale (caju), Astrocaryum vulgare (tucum), Copernicia prunifera (carnaúba), Bromelia sp. (croatá), Lecythis lurida (sapucaia), Bauhinia ungulata (pata-de-vaca), Parkia platycephala (faveira mentioned by the locals as toxic to cattle when consumed in excess), Mouriri guianensis (crioli) and Myrcia sp. (mariapreta) were mentioned by residents.

Plant parts used for this category and cited more frequently were the fruits of Astrocaryum vulgare and Parkia platycephala, flowers of Lecythis lurida (sapucaia) serving as food for livestock and leaves of Bauhinia ungulata (pata-de-vaca) being appreciated by goats mainly in the dry season. Astrocaryum vulgare and Parkia platycephala were the most representative species in this category, and the second one had the highest number of citations in the research by Ref. [18] in rural communities of the semiarid area of Piauí; by Ref. [19] in Cerrado areas in the municipality of Monsenhor Gil, Piaui, and; by Ref. [20] in the quilombola community Macacos, in São Miguel do Tapuio, Piauí state.

Regarding the species cited as toxic in the study area, species mentioned as harmful to cattle and goats were Aspidosperma pyrifolium and Manihot sp. (leaves), Parkia platycephala (fruit), Dimorphandra gardneriana (fruit) and Dioclea grandiflora (seeds). Dioclea grandiflora and
Manihot sp. were also mentioned as toxic in the study by Ref. [49] in Alagoinha, Pernambuco state. Aspidosperma pyrifolium and Manihot sp. were also mentioned as toxic by several authors $[53,54,14]$ in the Northeast of Brazil.

Regarding plants mentioned in the craft category, only Copernicia prunifera (carnaúba) was cited by residents for making brooms and fans, which are to be used in their own homes rather than having commercial value. The artisanal use of vegetation is rarely mentioned by residents in the study area, comprising only $1 \%$ of the citations.

The use of Copernicia prunifera as a craft can be observed in some ethnobotanical studies [18,20,23] conducted in communities São Miguel do Tapuio, Morro da Mariana and Barra Grande, indicating the importance of this species for traditional communities. It was observed that the species is of fundamental importance in the daily lives of the villagers in the study, and it is used in several tools that support the household service of the locals.

\section{Conclusions}

In this study we aimed to raise the species of native vegetation known and used for different purposes by Serragem villagers, in the municipality of Buriti dos Lopes, Piauí state. The use of native vegetation for several purposes is still a practice that has been quite common among villagers, and has a fundamental importance for it serves as alternative to perform many daily activities. Regarding the local flora, it was observed that it is preserved, even with the fact that residents use the species with logging and energy production purposes, because this way of handling results in an imbalance of natural resources, since there is no way to replanting seedlings of the plants used in the village.

On the other hand, it was observed that traditional knowledge in the village is getting more and more fragmented, especially concerning the youngsters who are moving to large urban centers in search of jobs. Thus, it is of fundamental importance to carry out studies in Ethnobotany aiming at rescuing this community knowledge under study, in order to avoid it to be forgotten, and to understand the relationship between this traditional community and the natural resources in the area.

Understanding how the traditional community uses natural resources is essential to develop conservation proposals and greater environmental sustainability. Finally, all this knowledge along with the scientific knowledge can help in practices of management, conservation and sustainable use of natural resources.

\section{References}

[1] Balick, M. J., and Cox, P. A. 1997. Plants, people and culture. New York: Scientific American Library.

[2] Martin, G. 1995. Ethnobotany: A methods manual. WWF International, UNESCO, Royal Botanic Gardens Kew, UK 
[3] Schultes, R. E., and Reis, S. 1995. Ethnobotany: Evolution of a discipline. Londres, Chapman \& Hall.

[4] Cotton, C. M. 1996. Ethnobotany: Principles and Applications. London. School of Life Sciences. Roehampton Institute, UK.

[5] Amorozo, M. C. M. 1996. A Abordagem Etnobotânica na Pesquisa de Plantas Medicinais. In: DI STASI, L. C. (Org.). Plantas medicinais: arte e ciência. Um guia de estudo interdisciplinar. São Paulo: UNESP.

[6] Amorozo, M. C. M., and Gely, A. 1988. Uso de plantas medicinais por caboclos do baixo Amazonas, Barbacema, Pará, Brasil. Boletim do Museu Paraense Emílio Goeldi 4: 47-131.

[7] Oliveira, F. C. S., Barros, R. F. M., and Moita Neto, J. M. 2010. Plantas medicinais utilizadas em comunidades rurais de Oeiras, semiárido piauiense. Revista Brasileira de Plantas Medicinais 12: 282-301.

[8] Simões, C. M. O., Mentz, L. A., Schenkel, E. P., Irgang, B. E., and Stehmann, R. J. 1989. Plantas da medicina popular no Rio grande do Sul. Porto Alegre: Ed. da UFRGS, 173p.

[9] Franco, E. A. P., and Barros, R. F. M. 2006. Uso e diversidade de plantas medicinais no Quilombo Olho D'água dos Pires, Esperantina, Piauí. Revista Brasileira de Plantas Medicinais 8 $78-88$

[10] Santos, A. B. N. 2010. Uso e Diversidade de Plantas Medicinais no Munícipio de Cajueiro da Praia, Piaú, Brasil. 2010. 27 f. Monografia (Graduação em Ciências Biológicas)Universidade Federal do Piauí, Parnaíba.

[11] Chaves, E. M. F., and Barros, R. F. M. 2012. Diversidade e uso de recursos medicinais do carrasco na APA da Serra da Ibiapaba, Piauí, Nordeste do Brasil. Revista Brasileira de Plantas Medicinais 14:476-486.

[12] Aguiar, L. C. G. G., and Barros, R. F. M. 2012. Plantas medicinais cultivadas em quintais de comunidades rurais no domínio do cerrado piauiense (Município de Demerval Lobão, Piauí, Brasil). Revista Brasileira de Plantas Medicinais 14: 419-434.

[13] Chaves, E. M. F. et al. 2014. Conhecimento Tradicional: A cultura das cercas de madeira no Piauí, nordeste do Brasil. Etnobiológica 12:31-43.

[14] Mello, G.W.S., Oliveira, D. M., Carvalho, C. J. S., Pires, L. V., Costa, F. A. L., Correa, R. F., and Silva, S. M. M. 2010 Plantas tóxicas para ruminantes e equídeos no Norte do Piauiense. Pesquisa Veterinária Brasileira 30: 1-9.

[15] Chaves, E. M. F. 2005. Florística e Potencialidades econômicas da vegetação de carrasco no município de Cocal, Piauí, Brasil. Teresina: UFPI, 2005. 112p. Dissertação (Mestrado) - Programa de Pós-Graduação em Desenvolvimento e Meio Ambiente. Universidade Federal do Piauí, Teresina.

[16] Franco, E. A. P. A. 2005. A Diversidade Etnobotânica no Quilombo Olho D'água dos Pires, Esperantina, Piauí, Brasil. Teresina, UFPI, 2005. Dissertação (Mestrado) - Programa de Pós-Graduação em Desenvolvimento e Meio Ambiente, Universidade Federal do Piauí, Teresina.

[17] Chaves, E. M. F., Barros, F. M., and Sérvio Júnior, E. M. 2006 Plantas do carrasco da Ibiapaba. Fundação de Amparo à Pesquisa do Estado do Piauí.

[18] Oliveira, F. C. S. 2008. Conhecimento botânico tradicional em comunidades rurais do semiárido Piauiense. 2008. 132f. Dissertação (Mestrado em Desenvolvimento e Meio Ambiente) - Universidade Federal do Piauí, Teresina.

[19] Santos, L. G. P. 2008. Florística e conhecimento botânico tradicional em áreas do cerrado no município de Monsenhor Gil, Piauí, Brasil. Teresina, UFPI, 2008. 101p. Dissertação (Mestrado) - Programa de Pós-Graduação em Desenvolvimento e Meio Ambiente, Universidade Federal do Piauí, Teresina.

[20] Vieira, F. J. 2008. Uso e diversidade dos recursos vegetais utilizados pela Comunidade Quilombola dos Macacos em São Miguel do Tapuio. 2008. 124p. Dissertação (Mestrado em Desenvolvimento e Meio Ambiente) - Universidade Federal do Piauí, Teresina.

[21] Silva, M. P. 2010. Conhecimento Etnobotânico de Comunidades Rurais da Serra de Campo Maior - Piauí, Brasil. 2010. 173 f. Dissertação (Mestrado em Desenvolvimento e Meio Ambiente) - Universidade Federal do Piauí, Teresina.

[22] Amorim, A. N. 2010. Etnobiologia da comunidade de pescadores artesanais urbanos do bairro Poti Velho, Teresina/PI, Brasil. 2010. 122 f. Dissertação (Mestrado em Desenvolvimento e Meio Ambiente) - Universidade Federal do Piauí.

[23] Sousa, R. S. 2010. Etnobotânica e etnozoologia de comunidades pesqueiras da área de proteção ambiental (APA) do delta do Parnaíba, nordeste do Brasil. 2010. $176 \mathrm{f}$. Dissertação (Mestrado em Desenvolvimento e Meio Ambiente) - Universidade Federal do Piauí, Teresina.

[24] Ibge. 2010. Instituto Brasileiro de Geografia e Estatística. $2010 . \quad$ Disponível em: $<$ http://cidades.ibge.gov.br/painel/painel.php?codmun=220200> Acesso em: 02 julho 2014.

[25] Cepro-2000. Fundação Centro de Pesquisas. Perfil dos Municípios. Teresina: Fundação CEPRO, 420p.

[26] Google Mapas 2013. Disponível em: $<$ https://maps.google.com.br/maps?hl=ptBR\&tab=wl\&output $=$ classic \&dg=brw $>$ Acesso em: 20 junho 2014 .

[27] Bayley, K. D. 1982. Methods of social research. New York: Free Press., 553 p.

[28] IBGE. Censo 2009. disponível em: $<$ http://www.ibge.gov.br/home/estatistica/economia/perfilmun ic/2009/> Acesso em: 12 abril 2014.

[29] Bernard, H. R. 1988. Research methods in cultural anthropology. Newbury Park, CA: SagePubl., 520 p.

[30] Albuquerque, U. P. de, Lucena, R. F. P. de, and Cunha, L. V. F. C. 2008. Métodos e técnicas na pesquisa etnobotânica. 2ed. Recife: Comunigraf.

[31] Phillips, O., and Gentry, A. H. 1993. The useful plants of Tambopata, Peru: I. Statistical hypothesis tests with a new quantitative technique. Economic Botany 47: 15-32.

[32] Phillips, O., Gentry, A. H., Reynel, C., Wilkin, P., and GálvesDurand, B.C. 1994. Quantitative ethnobotany and Amazonian conservation. Conserv. Biol. 8:225-248.

[33] Rossato, S. C. 1996. Uso de plantas por comunidades caiçaras do litoral norte do estado de São Paulo. Dissertação. Universidade de São Paulo, São Paulo. 
[34] Lima, R. X., Silva, S. M., and Silva, Y. S. K. L. 2000. Etnobiologia de comunidades continentais da Área de Proteção Ambiental de Guaraqueçaba, Paraná, Brasil. Etnoecológica 4: 33-54. [35]

[35] OMS (Organização Mundial de Saúde) 2008. CID - 10: Classificação Estatística Internacional de Doenças e Problemas Relacionados à Saúde. Editora da Universidade de São Paulo, São Paulo.

[36] Mori, A. S. et al. 1989. Manual de manejo do herbário fanerogâmico. Centro de Pesquisa do Cacau. Ilhéus, 104 p.

[37] Souza, V. C., and Lorenzi, H. 2012. Botânica Sistemática Guia ilustrado para identificação das famílias de Angiospermas da flora brasileira, baseado em APG III. Nova Odessa, SP: Instituto Plantarum, 640p.

[38] Lista de Espécies da Flora do Brasil. 2012. Jardim Botânico do Rio de Janeiro. Disponível em: $<$ http://floradobrasil.jbrj.gov.br/>. Acesso em: 25 Julho 2014.

[39] Meireles, V. J. S. 2012. Etnobotânica e caracterização da pesca na comunidade Canárias, Reserva Extrativista Marinha do Delta do Parnaíba, Nordeste do Brasil. 2012. $164 \mathrm{f}$. Dissertação (Mestrado em Desenvolvimento e Meio Ambiente) - Universidade Federal do Piaú, Teresina.

[40] Araujo, M. P. 2013. Etnobotânica e Etnozoologia da comunidade pesqueira Passarinho, Ilha das Canárias, Reserva Extrativista Marinha do Delta do Parnaíba, Araioses/MA/Brasil. Teresina: UFPI, 2013.143p. Dissertação (Mestrado) - Programa de Pós-Graduação em Desenvolvimento e Meio Ambiente. Universidade Federal do Piauí, Teresina.

[41] Borges, R., and Peixoto, A. 2009. Conhecimento e uso das plantas em uma comunidade caiçara do litoral sul do Estado do Rio de Janeiro, Brasil. Acta Botânica Brasílica 23: 769-779.

[42] Miranda, T. M., Hanazaki, N. Govene, S. J., and Alves, D. M. M. 2011. Existe utilização efetiva dos recursos vegetais conhecidos em comunidades caiçaras da Ilha do Cardoso, Estado de São Paulo, Brasil? Rodriguésia 62: 153-169.

[43] Abreu, J. R. 2000. Diversidade de recursos vegetais do cerrado utilizados pelos quilombolas Mimbó (Amarante Piauí, Brasil). Recife: UFPE, 2000. 69 p. Dissertação (Mestrado) Programa de Pós-Graduação em Biologia Vegetal, Universidade Federal de Pernambuco. Recife.

[44] Roque, A. A., Rocha, R. M., and Loiola, M. I. B. 2010. Uso e diversidade de plantas medicinais da caatinga na comunidade rural de Laginhas, município de Caicó, Rio Grande do Norte (Nordeste do Brasil). Revista Brasileira de Plantas Medicinais 12: 31-42.

[45] Roque, A. A., Loiola, M. I. B. 2013. Potencial de uso dos recursos vegetais em uma comunidade rural no semiárido Potiguar. Revista Caatinga 26: 88-98.

[46] Val. E. J. 2006. Espécies arbóreas medicinais nativas da localidade Marajá no município de Caxingó-PI, Monografia (Especialização em Paisagismo e Manejo Ambiental) Faculdade de Geografia, Universidade Estadual do Piauí, Parnaíba, 34f.

[47] Marinho, M. G. V., Silva, C. C., and Andrade, L. H. C. 2011. Levantamento etnobotânico de plantas medicinais em área de caatinga no município de São José de Espinharas, Paraíba, Brasil. Revista Brasileira de Plantas Medicinais 13: 170-182.

[48] Silva, T. S., and Freire, E. M. X. 2010. Abordagem etnobotânica sobre plantas medicinais citadas por populações do entorno de uma unidade de conservação da caatinga do Rio Grande do Norte, Brasil. Revista Brasileira de Plantas Medicinais 12: 427-435.

[49] Albuquerque, U.P., and Andrade. L.H.C. 2002. Conhecimento botânico tradicional e conservação em uma área de caatinga no estado de Pernambuco, Nordeste do Brasil. Acta Botanica Brasilica 16: 273-85.

[50] Silva, S. 2014. Conhecimento e uso de plantas medicinais em uma comunidade rural no município de Cuitegi, Paraíba, Nordeste, Brasil. 64 p. Paraíba: UEPB, 2014. Monografia (Conservação do Meio Ambiente e Sustentabilidade dos Ecossistemas).

[51] Mendes, B. V. 1997. Biodiversidade e desenvolvimento sustentável do semiárido. SEMACE: Fortaleza. 108p.

[52] Lucena, C. M. et al. 2012. Conhecimento local sobre cactáceas em comunidades rurais na mesorregião do sertão da Paraíba. Biotemas 25: 282-291.

[53] Silva, D. M.S., Correa, F. R. C., Medeiros, R. M. T., and Oliveira, O. F. 2006. Plantas tóxicas para ruminantes e equídeos no Seridó Ocidental e Oriental do Rio Grande do Norte. Pesquisa Veterinária Brasileira 26: 223-236.

[54] Assis, S. T., Medeiros, R. M. T., Araújo, J. A. S., Dantas, A. F. M., and Correa, F. R. 2009. Intoxicações por plantas em ruminantes e equídeos no Sertão Paraibano. Pesquisa Veterinária Brasileira 29: 919-924. 